\title{
The Advantages of Using Augmented Reality (AR) Technology in Midwifery Education: A Literature Review
}

\author{
$1^{\text {st }}$ Astuti Dyah Bestari \\ Departement of Public Health \\ Universitas Padjadjaran \\ Sumedang, Indonesia \\ astuti.dyah.bestari@unpad.ac.id
}

\author{
$2^{\text {nd }}$ Guswan Wiwaha \\ Departement of Public Health \\ Universitas Padjadjaran \\ Sumedang, Indonesia
}

\begin{abstract}
Introduction: The Indonesian government has expressed the importance of the implementation of quality assurance systems through national standards of higher education (Permenristekdikti 44/2015) including educational infrastructure standards which educational media is one of them. In the industrial revolution 4.0 era, educational media must be adapted with advancing technology and providing the convenience of students in the learning process. For midwife, the understanding of anatomy and physiology is mandatory. Augmented Reality (AR) was the technology that will be able to bridge between cyberspace and the real world, so it will be facilitate the understanding of students. The aim of this literature review was to discover the benefits of integrated modules for the midwifery education. Methods: This literature review is the first step in a study of the development of integrated $A R$ module. Literature was formed by using criteria that are relevant to the objectives of the study, which contain articles about $A R$ applications and their benefits in health education. Results: A total of 12 articles (2012-2018) that were relevant had been found in accordance with the relevant criteria. The AR application has the benefits of medical students among them 1) increasing the student's knowledge retention, 2) increasing the student's learning motivation. Conclusion: AR integrated modules have been proven having benefits for medical education. For this reason, the research will continue in the next stage, namely the making of AR integrated modules and their application to midwifery education.
\end{abstract}

\section{Keywords-Augmented Reality, Technology, Midwifery \\ I. INTRODUCTION}

National standards of higher education (Standar Nasional Pendidikan Tinggi/SNPT) which is contained in the Ministry of Research, Technology and Higher Education regulation number 44/2015 (Permenristekdikti 44/2015) become a basic quality assurance both internal and external; which aims was to ensure the achievement of educating the life of the nation, advancing science and technology by applying the value of humanities as well as the culture and sustainable empowerment of the Indonesian nation. To achieve this goal, eight standards have been established, one of which is the standard competency of graduates.

The main of midwife competency is able to carry out midwifery care to the pregnancy women, delivery mothers, post-partum mothers, infants and giving a contraceptives. The complexity of these competencies requires a good understanding of human anatomy and physiology. The learning process requires complete equipment's such as phantoms or models for the human body. The high price of these equipments caused inappropriate numbers of availability for students. In addition to phantoms and models, as a two dimention (2D) educational media in the form of pictures and videos also have limitations. 2D image media cannot provide depictions of an intact human anatomy so that students' imagination is needed; while not all students can do it. [1]

At present, the world is entering the industrial revolution 4.0 era which is marked by the existence of cyber physics and manufacturing collaboration. This era requires demanding changes in various fields, including of educational fields. Education must be able to prepare students to work and solve problems that will arise using the latest technology that may not have been discovered in the current education period. Enhancing digitalization of manufacturing continues to develop and one of them is encouraged by a new form of interaction with humane machinery. [2] One of the interactions is in the form of Virtual Reality (VR) and Augmented Reality (AR). AR is a technology that will be able to bridge between cyberspace and the real world. In the fields of education, educational media using AR are considered interesting because they can create a unique learning environment and students can learn to explore objects that are being learned in 3D. Students will be strengthened by perception and imagination through the utilization of AR using images and colours that appear to be true in front of their faces. The use of AR in health education has been proven having the benefits for the students' learning process. 
The study's result stated that the use of AR as a learning medium for practical simulation has been proven to increase the knowledge retention of students compared to the students who learn only from media in the form of pictures. Other studies suggested that the use of AR has been shown to increase the learning motivation of students. For educational institutions, the use of AR learning media also has specific effects on funding issues. The use of AR as a substitute for phantom and human body models can have a longer usage period so this is more cost-effective. Every student can access AR from her cell phone, so the need for phantom and human body models will be reduced. AR is also expected to raise the standard of education infrastructure, especially in terms of educational media. The aim of this literature review is to determine the advantages of using Augmented Reality (AR) technology for midwifery education.

\section{METHOD}

This literature review is the first step of developing integrated module research with Augmented Reality (AR) for midwifery education. This literature review will cover six steps 1) select a topic, 2) develop the tools for argument, 3) search the literature, 4) survey the literature, 5) critique the literature and 6) write the review.[3] Topics of the problems drawn in the literature review are the benefits of AR for the midwifery education. The next step is the process of searching for sources of literature related to the predetermined topics. The study's result that has been published in the form of journal and book was got by searching machine assistance of Google with the key word "Augmented Reality for medical Education". The article was obtained from international and national journals.

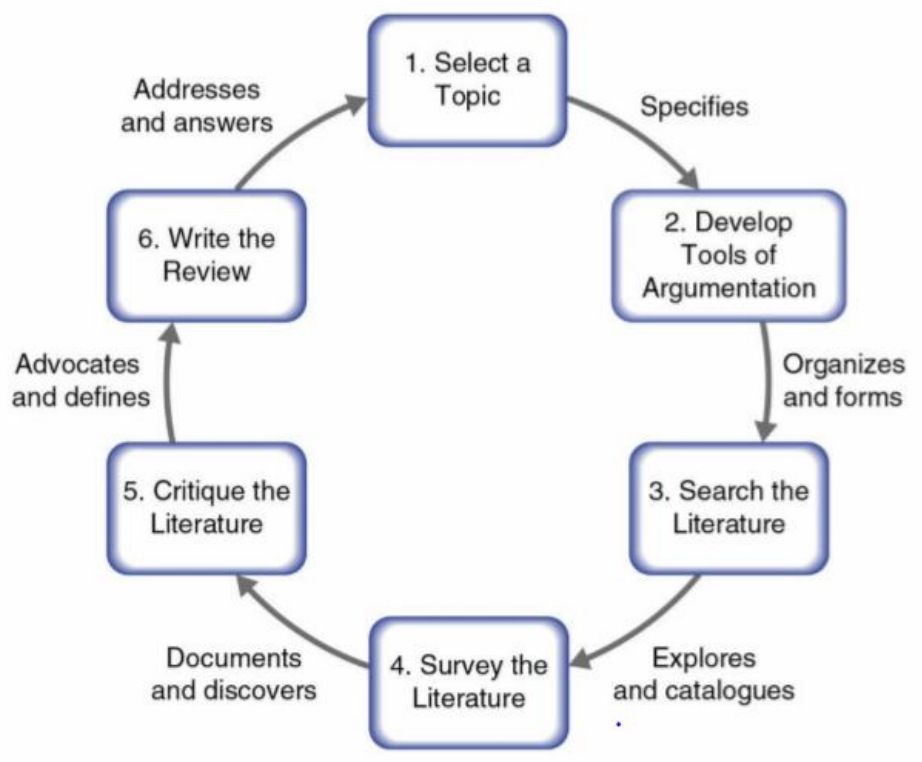

Fig. 1. The literature review model

III. RESULT

There 24 articles were obtained related to the objectives which contained the benefits of AR technology in the field of education. A total of 12 articles were selected after passing the analysis by considering the purpose of the research to discover the benefits of the use of AR technology in the field of health education. The benefits of using AR technology are more clearly explained in the following table :

\begin{tabular}{|c|c|c|c|}
\hline Authors & Year & $\begin{array}{c}\text { Types of } \\
\text { Articel }\end{array}$ & Result \\
\hline Mehmet Kesim, Yasin Ozarslan ${ }^{\mathrm{a}}$ & 2012 & $\begin{array}{l}\text { Literature } \\
\text { Review }\end{array}$ & $\begin{array}{l}\text { AR facilitates the students in learning process because AR can give a } \\
\text { real description }\end{array}$ \\
\hline Nor Farhah Saidin ${ }^{b}$ & 2014 & $\begin{array}{l}\text { Literature } \\
\text { Review }\end{array}$ & $\begin{array}{l}\text { The benefit of AR technology as follows: AR features are able to } \\
\text { engage students in learning processes and help improve their } \\
\text { visualisation skills } \\
\text { - AR can help the teachers to explain well and make the students } \\
\text { easily understand what they are taught. } \\
\text { - AR technology has received positive feedback from participants } \\
\text { and students who have shown their interest in using AR in their } \\
\text { learning processes }\end{array}$ \\
\hline Carolien Kamphuis $^{\mathrm{c}}$ & 2014 & $\begin{array}{l}\text { Literature } \\
\text { Review }\end{array}$ & $\begin{array}{l}\text { AR has some benefits, as follows: } \\
\text { - } \quad \text { giving real learning experience } \\
\text { - } \quad \text { stimulating the students' learning process } \\
\text { clinical learning for the students becomes better because they } \\
\text { get the description before going to clinic }\end{array}$ \\
\hline Egui Zhu ${ }^{\mathrm{d}}$ & 2014 & $\begin{array}{c}\text { Literature } \\
\text { Review }\end{array}$ & The use of AR can increase the competencies the health education \\
\hline
\end{tabular}




\begin{tabular}{|c|c|c|c|}
\hline Authors & Year & $\begin{array}{c}\text { Types of } \\
\text { Articel } \\
\end{array}$ & Result \\
\hline Phil Diegmann ${ }^{\mathrm{e}}$ & 2015 & $\begin{array}{l}\text { A Systematic } \\
\text { Literature } \\
\text { Review }\end{array}$ & $\begin{array}{l}\text { AR can increase the learning result and the motivation and can train } \\
\text { the students' skill }\end{array}$ \\
\hline Dedi Eko Nurcahyo ${ }^{\mathrm{f}}$ & 2015 & $\begin{array}{c}\text { Literature } \\
\text { Review }\end{array}$ & $\begin{array}{l}\text { Nowadays, AR technology develops in android devices so it is } \\
\text { possible AR can be improved. }\end{array}$ \\
\hline Tashko Rizov, Elena Rizova ${ }^{g}$ & 2015 & $\begin{array}{l}\text { Observational } \\
\text { Study }\end{array}$ & $\begin{array}{l}\text { AR has some benefits including : } \\
\text { - Maintaining the students' attention longer } \\
\text { - Increasing the students' motivation } \\
\text { - } \quad \text { Assisting the students' to be faster in comprehending }\end{array}$ \\
\hline Ilmawan Mustaqim ${ }^{\mathrm{h}}$ & 2016 & $\begin{array}{l}\text { Literature } \\
\text { Review }\end{array}$ & $\begin{array}{l}\text { AR has some benefit as follows: } \\
\text { - Increasing the students' learning interest } \\
\text { - Assisting the students' imagination } \\
\text { - Stimulating the students to think critically }\end{array}$ \\
\hline E. Z. Barsomi & 2016 & $\begin{array}{l}\text { Systematic } \\
\text { Review }\end{array}$ & The use of AR assist the implementation of blended learning \\
\hline Tasneem Khan ${ }^{\mathrm{j}}$ & 2019 & $\begin{array}{c}\text { Literature } \\
\text { Review }\end{array}$ & $\begin{array}{l}\text { Increase the students' learning motivation, attention, satisfaction and } \\
\text { self-confidence }\end{array}$ \\
\hline Murat Akçayır ${ }^{k}$ & 2017 & $\begin{array}{l}\text { Literature } \\
\text { Review }\end{array}$ & AR can increase the learning achievement \\
\hline Min-Chai Hsieh ${ }^{1}$ & 2018 & $\begin{array}{l}\text { Literature } \\
\text { Review }\end{array}$ & $\begin{array}{l}\text { The uses of VR, AR and MR can increase the effectiveness and } \\
\text { efficiency of medical learning process that finally will be able to } \\
\text { increase health services }\end{array}$ \\
\hline
\end{tabular}

\section{DISCUSSION}

According to the result of table 1, it can be concluded that the use of AR on the education process has some good benefits both for the students and the lecturer are as follows:

\section{A. For the students}

- Increase the retention of the students' knowledge Health students such as midwifery, need high imagination to understand some understanding of the anatomy of human organs in humans. The obstacle faced today is the difficulty of students to imagine the human organs of the human body because the learning media that is felt cannot provide real images that up to the point of demanding resources for students, even though not all students have high imagination. The use of AR technology as a learning medium is able to bridge the gap between the cyber world and the real world. [4] This is what will help the imagination of the students so the retention of the students' knowledge become better than the students who study with conventional media such as three-thirds pictures and even phantom.
- Increase the students' learning motivation AR technology is an interesting medium with the features not possessed by conventional learning media. In addition, the use of AR technology through smart phones is felt to attract the students' attention. When someone is interested in something, the motivation will increase to learn more. If the students have better motivation in learning, surely, the knowledge they have will retain longer. Secondly, it is hoped that this will improve students' academic achievement.

\section{B. For Lecturers}

The benefits felt by the lecturers of the use of AR technology are that the lecturers are facilitated in in the process of conveying special materials that require a visual aid. Conveying and giving understanding to the students about human organs is not an easy thing, but with the use of AR technology, the lecturers are facilitated to convey the materials. Visualization of AR in $3 \mathrm{D}$ is regarded being able to give the real description compared to the conventional media used by the students in the form of pictures and video. Authors and Affiliations 


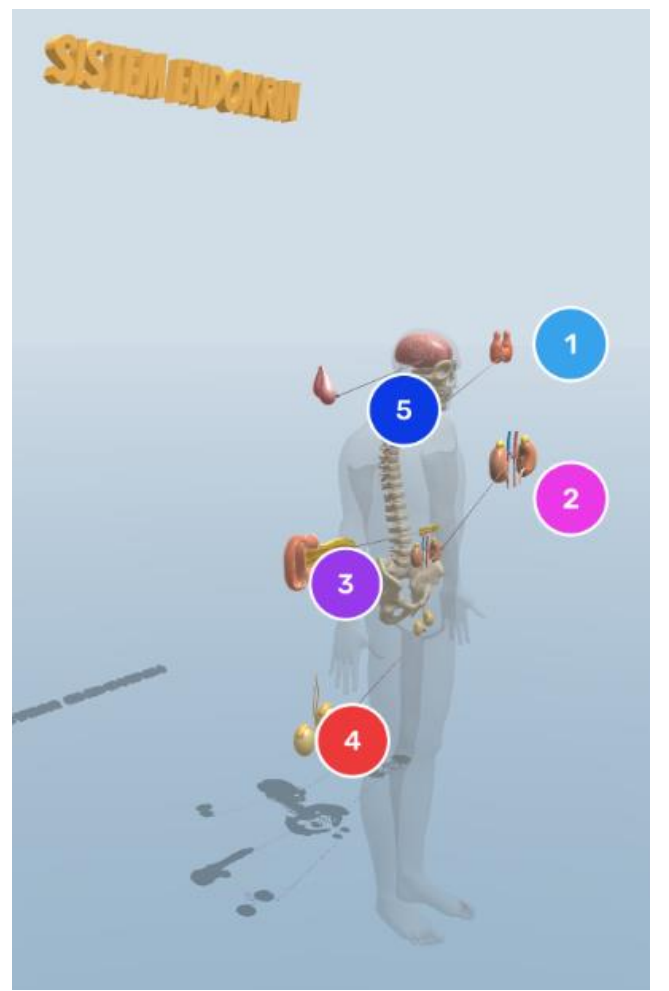

Fig. 2. Example of Augmented Reality (AR) Endocrine System

\section{CONCLUSIONS}

Based on the results of the literature review it can be concluded that the use of AR technology has benefits for midwifery education; both for students and lecturers. For students, the delivery of interesting material using AR can increase learning motivation so as to increase the retention of the knowledge they have. While for lecturers, AR technology makes it easy to deliver material because it provides a real description of the object being explained.

\section{ACKNOWLEDGMENT}

We would like to express deepest appreciation who helped us in making this literature review, to Pusat Studi Sistem Kesehatan dan Inovasi Pendidikan (SKIP-Nakes) who have helped in making AR concepts. We also would like to thank to Assemblr for helping teach AR application. Finally, we thank all parties and colleagues at Program Studi D IV Kebidanan Universitas Padjadjaran.

\section{REFERENCES}

[1] N. N. Pascal Fallavollita, "No Title," in Mixed and Augmented Reality in Medicine, J. W. Terry M Peters, Cristian A. Linte, Ziv Yaniv, Ed. Taylor \& Francis Group, 2019, p. 217

[2] Sukartono, "Revolusi Industri 4.0 dan Dampaknya terhadap Pendidikan di Indonesia," FIP PGSD Univ. Muhammadiyah Surakarta, pp. 1-21, 2018

[3] B. T. M. Machi A Lawrence, The Literature Review : Six Steps to Success, 3rd ed. SAGE Publications Ltd., 2016.

[4] M. Kesim and Y. Ozarslan, "Augmented Reality in Education: Current Technologies and the Potential for Education," Procedia Soc. Behav. Sci., vol. 47, no. 222, pp. 297-302, 2012.
[5] N. F. Saidin, N. Dayana, A. Halim, and N. Yahaya, "The Potential Of Augmented Reality Technology In Education: A Review Of Previous Research," pp. 0-7.

[6] C. Kamphuis, E. Barsom, M. Schijven, and N. Christoph, "Augmented reality in medical education?," Perspect. Med. Educ., vol. 3, no. 4, pp. 300-311, 2014.

[7] E. Zhu, A. Hadadgar, I. Masiello, and N. Zary, "Augmented reality in healthcare education: An integrative review," PeerJ, vol. 2014, no. 1, pp. 1-17, 2014.

[8] P. Diegmann Manuel Schmidt-Kraepelin Sven Eynden Dirk Basten, "Wirtschaftsinformatik 3-6-2015 of Augmented Reality in Educational Environments-A Systematic Literature Review," Proc. 12th Int. Conf. Wirtschaftsinformatik, p. 103, 2015.

[9] D. E. Nurcahyo and B. S. Hantono, "Pemanfaatan Augmented Reality Dalam Dunia Pendidikan untuk mempelajari Anatomi Tubuh Manusia Berbasis Android,” Jurnal, vol. 2015, no. Sentika, pp. 193-198, 2015

[10] E. R. Tashko Rizov, "Augmented Reality As A Teaching Tool In," vol. 3 , no. 1,2015 .

[11] I. Mustaqim, "Pemanfaatan Augmented Reality Sebagai Media Pembelajaran," vol. 13, no. 2, pp. 174-183, 2016.

[12] E. Z. Barsom, M. Graafland, and M. P. Schijven, "Systematic review on the effectiveness of augmented reality applications in medical training," Surg. Endosc., vol. 30, no. 10, pp. 4174-4183, 2016.

[13] T. Khan, K. Johnston, and J. Ophoff, "The Impact of an Augmented Reality Application on Learning Motivation of Students," Adv. Human-Computer Interact., vol. 2019, 2019.

[14] M. Akçayır and G. Akçayır, "Benefits and challenges associated with augmented reality for education: A systematic review of the literature," Educ. Res. Rev., vol. 20, pp. 1-11, 2017.

[15] M. C. Hsieh and J. J. Lee, "Preliminary Study of VR and AR Applications in Medical and Healthcare Education," J. Nurs. Heal. Stud., vol. 03, no. 01, pp. 1-5, 2018. 